\title{
CARDIAC OUTPUT AND INTRACARDIAC PRESSURES IN PATIENTS WITH ARTERIOVENOUS FISTULAS ${ }^{1}$
}

\author{
By F. H. EPSTEIN,2 O. W. SHADLE, T. B. FERGUSON, AND M. E. MCDOWELL ${ }^{3}$ \\ (From the Department of Cardio-respiratory Diseases, Army Medical Service Graduate School, \\ Washington, D. C.)
}

(Submitted for publication December 1, 1952; accepted February 25, 1953)

\section{INTRODUCTION}

Although many measurements have been made of hemodynamic alterations in patients and animals with a peripheral arteriovenous fistula, the exact nature of some of these changes and the mechanisms responsible for them remain in dispute. The present study was undertaken to reinvestigate the effects of occluding and releasing an arteriovenous fistula on cardiac output and intracardiac pressures in man.

\section{METHODS}

Subjects were seven young soldiers with a traumatic peripheral arteriovenous fistula in the femoral or popliteal region who had been wounded two to four months before their initial study. After the patient had been sedated with Nembutal, $0.1 \mathrm{gm}$. by mouth, the heart was catheterized with a No. 7F catheter 4 via an antecubital vein, and the tip of the catheter introduced into the main pulmonary artery. An inlying No. 18 needle was then inserted in the opposite brachial artery. Pressures were recorded with a Sanborn electromanometer simultaneously from the catheter and the brachial artery, before, during and after occluding the arteriovenous fistula manually or with a sphygmomanometer cuff inflated above arterial pressure. These measurements were repeated with the tip of the cardiac catheter successively in the pulmonary artery, right ventricle and right atrium. In all patients control measurements were made while occluding the arterial circulation to the opposite leg in the same way, a procedure which did not significantly alter systemic blood pressure, intracardiac pressures or cardiac output. "Mean" pressures were obtained by electrical integration. Cardiac output was measured by the dye dilution method, using a modification of the constant flow photometer of Friedlich, Heimbecker, and Bing (1). The criterion for the use of this instrument and its modifications has been described elsewhere (2). Ten to 20

\footnotetext{
1 Presented in part before the American Federation for Clinical Research, Atlantic City, N. J., May 4, 1952.

2 Captain, M.C. Present address: First General Dispensary, Fort Richardson, Alaska.

${ }^{3}$ Major, M.C.

U. S. Catheter and Instrument Co., Glens Falls, New
}

mgm. of T 1824 in 2 to $4 \mathrm{cc}$. of saline were injected rapidly through a catheter into the right atrium or ventricle and a continuous photoelectric record of the concentration of the dye in arterial blood was obtained. No extrasystoles or other arrhythmias were observed as a result of this procedure. A special effort was made to permit not more than six minutes to elapse between successive measurements of cardiac output. In a few instances in which the heart was not catheterized, the dye was injected into a subclavian vein via a $30 \mathrm{~cm}$. length of polyethylene tubing inserted through a vein in the antecubital fossa.

\section{RESULTS (TABLE I)}

Compression of the fistula produced an increase in diastolic arterial pressure in every case. Systolic pressure usually rose somewhat less; the pulse pressure was therefore narrowed. Following the abrupt initial rise, a few oscillations in blood pressure were usually seen, after which the pressure stabilized at a level higher than that existing when the fistula was open, but lower than that reached immediately following occlusion of the shunt. The form of the pulse wave was altered (Figure 1) with the dicrotic notch appearing higher on the descending limb, presumably a reflection of the increase in peripheral resistance. Patients with the largest arteriovenous communications as estimated at the time of surgery tended to have the most marked changes in blood pressure when the fistula was compressed or released. The pulse rate slowed when the fistula was occluded and became more rapid when it was released (Nicoladoni-Branham sign) $(3,4)$. These findings confirm the reports of others.

Cardiac output was measured in six of seven subjects. The "resting" cardiac index was above 4 liters per min. per square meter in four patients and fell considerably in all four when the fistula was occluded (Figure 2). This resulted from a decreased stroke volume and a slowing of the cardiac rate. 
TABLE I

\begin{tabular}{|c|c|c|c|c|c|c|c|c|c|}
\hline \multirow{2}{*}{$\begin{array}{l}\text { Patient, } \\
\text { Location } \\
\text { of fistula, } \\
\text { Surface } \\
\text { area }\left(M^{2}\right)\end{array}$} & \multirow[b]{2}{*}{ Procedure } & \multicolumn{4}{|c|}{ Pressure } & \multirow[b]{2}{*}{$\begin{array}{c}\text { Pulse } \\
\text { rate }\end{array}$} & \multirow[b]{2}{*}{ c.o. } & \multirow[b]{2}{*}{$\begin{array}{l}\text { Stroke } \\
\text { vol. }\end{array}$} & \multirow[b]{2}{*}{ C. I. } \\
\hline & & $\begin{array}{c}\text { Brachial } \\
\text { artery }\end{array}$ & $\begin{array}{c}\text { Right } \\
\text { atrium } \\
\text { mean }\end{array}$ & $\begin{array}{l}\text { Right } \\
\text { vent. } \\
\text { diast. }\end{array}$ & $\begin{array}{l}\text { Pulm. } \\
\text { artery } \\
\text { mean }\end{array}$ & & & & \\
\hline $\begin{array}{l}\text { F. R. } \\
\text { Femoral } \\
1.61\end{array}$ & $\begin{array}{l}\text { Control } \\
\text { Occlude } \\
\text { Recovery }\end{array}$ & $\begin{array}{l}m m . H g \\
110 / 62 \\
111 / 78 \\
108 / 60\end{array}$ & $\begin{array}{c}m m . \mathrm{Hg} \\
4 \\
3 \\
4\end{array}$ & $\begin{array}{c}m m . B g \\
3 \\
2.5 \\
3.5\end{array}$ & $\begin{array}{c}m m . H_{g} \\
15 \\
10 \\
16\end{array}$ & $\begin{array}{c}\text { beats/min. } \\
76 \\
70 \\
76\end{array}$ & $\begin{array}{c}c c . / \min . \\
7,644 \\
4,840 \\
6,983\end{array}$ & $\begin{array}{l}c c . \\
101 \\
69 \\
92\end{array}$ & $\begin{array}{c}c c . / \min . / M \\
4,748 \\
3,006 \\
4,337\end{array}$ \\
\hline $\begin{array}{l}\text { H. B. } \\
\text { Poplit. } \\
1.69\end{array}$ & $\begin{array}{l}\text { Control } \\
\text { Occlude } \\
\text { Recovery }\end{array}$ & $\begin{array}{l}110 / 50 \\
111 / 65 \\
105 / 50\end{array}$ & $\begin{array}{l}4 \\
4 \\
4\end{array}$ & $\begin{array}{l}5.5 \\
4 \\
5\end{array}$ & $\begin{array}{l}16 \\
13.5 \\
15\end{array}$ & $\begin{array}{l}72 \\
54 \\
73\end{array}$ & $\begin{array}{l}\mathbf{7 , 7 8 2} \\
\mathbf{5 , 2 9 1} \\
\mathbf{9 , 0 7 2}\end{array}$ & $\begin{array}{r}108 \\
98 \\
124\end{array}$ & $\begin{array}{l}4,605 \\
3,131 \\
5,368\end{array}$ \\
\hline $\begin{array}{l}\text { E. B. } \\
\text { Femoral } \\
1.78\end{array}$ & $\begin{array}{l}\text { Control } \\
\text { Occlude } \\
\text { Recovery }\end{array}$ & $\begin{array}{l}110 / 56 \\
120 / 70 \\
108 / 53\end{array}$ & $\begin{array}{l}3.5 \\
3 \\
3.5\end{array}$ & & & $\begin{array}{l}80 \\
66 \\
83\end{array}$ & $\begin{array}{l}9,166 \\
6,092\end{array}$ & $\begin{array}{r}115 \\
92\end{array}$ & $\begin{array}{l}5,149 \\
3,422\end{array}$ \\
\hline $\begin{array}{l}\text { A. D. } \\
\text { Femoral } \\
2.07\end{array}$ & $\begin{array}{l}\text { Control } \\
\text { Occlude } \\
\text { Recovery }\end{array}$ & $\begin{array}{r}97 / 55 \\
103 / 65 \\
95 / 55\end{array}$ & $\begin{array}{l}7.5 \\
7.5 \\
7.5\end{array}$ & $\begin{array}{l}8 \\
8 \\
8\end{array}$ & $\begin{array}{l}14.5 \\
13.5 \\
14.5\end{array}$ & $\begin{array}{l}70 \\
50 \\
70\end{array}$ & $\begin{array}{l}8,613 \\
5,053\end{array}$ & $\begin{array}{l}123 \\
101\end{array}$ & $\begin{array}{l}4,161 \\
2,441\end{array}$ \\
\hline $\begin{array}{l}\text { O. C. } \\
\text { Femoral } \\
1.85\end{array}$ & $\begin{array}{l}\text { Control } \\
\text { Occlude } \\
\text { Recovery }\end{array}$ & $\begin{array}{l}112 / 66 \\
118 / 70 \\
112 / 62\end{array}$ & $\begin{array}{l}6 \\
6 \\
6\end{array}$ & $\begin{array}{l}4 \\
4 \\
4\end{array}$ & $\begin{array}{l}14 \\
14 \\
14\end{array}$ & $\begin{array}{l}74 \\
65 \\
80\end{array}$ & $\begin{array}{l}6,580 \\
6,526\end{array}$ & $\begin{array}{r}89 \\
100\end{array}$ & $\begin{array}{l}3,560 \\
3,530\end{array}$ \\
\hline $\begin{array}{l}\text { H. F. } \\
\text { Poplit. } \\
1.79\end{array}$ & $\begin{array}{l}\text { Control } \\
\text { Occlude } \\
\text { Recovery }\end{array}$ & $\begin{array}{l}134 / 78 \\
138 / 87 \\
130 / 80\end{array}$ & $\begin{array}{l}4 \\
4 \\
4\end{array}$ & $\begin{array}{l}8 \\
8 \\
8.5\end{array}$ & $\begin{array}{l}17 \\
17 \\
17\end{array}$ & $\begin{array}{l}63 \\
60 \\
60\end{array}$ & $\begin{array}{l}4,837 \\
5,788 \\
5,880\end{array}$ & $\begin{array}{l}77 \\
96 \\
95\end{array}$ & $\begin{array}{l}2,702 \\
3,233 \\
3,285\end{array}$ \\
\hline $\begin{array}{l}\text { W. R. } \\
\text { Femoral } \\
1.73\end{array}$ & $\begin{array}{l}\text { Control } \\
\text { Occlude } \\
\text { Recovery }\end{array}$ & $\begin{array}{l}110 / 58 \\
113 / 62 \\
102 / 53\end{array}$ & $\begin{array}{l}6.5 \\
6.5 \\
6.5\end{array}$ & $\begin{array}{l}\mathbf{5} \\
\mathbf{5} \\
\mathbf{5}\end{array}$ & $\begin{array}{l}20 \\
19 \\
20\end{array}$ & $\begin{array}{l}84 \\
64 \\
90\end{array}$ & & & \\
\hline
\end{tabular}

At least one minute was allowed for pressures and flows to stabilize after occluding or releasing a fistula, before the above measurements were recorded. Each pressure is the average of 30 consecutive beats, to the nearest half-millimeter $\mathrm{Hg}$. Values in boldface in the same horizontal line were recorded simultaneously.

In contrast to these large changes in cardiac output, the small or equivocal concomitant change in pressure in the right atrium and ventricle was a striking observation. In two patients (F. R. and E. B.) a slight fall in mean right atrial pressure was consistently observed when the fistula was occluded, together with a rise when it was released. Two others, however $(\mathrm{H}$. B. and $\mathrm{A}$. D.), exhibited no change in mean right atrial pressure during this maneuver. A slight fall in diastolic pressure in the right ventricle was observed to accompany a diminished stroke volume in two patients (F. R. and H. B.) but not in a third (A. D.). Mean pressure in the pulmonary artery fell when the fistula was occluded and rose when it was opened, in three patients who exhibited a significant reduction in cardiac output.

In two patients (O. C. and H. F.) the cardiac index was not initially elevated and did not decrease when the arteriovenous shunt was compressed. Although this maneuver produced the expected increase in arterial pressure and slowing of the pulse rate there was no change in mean right atrial pressure, diastolic right ventricular pressure, or mean pressure in the pulmonary artery.

In four patients the resting cardiac output was remeasured four to eight weeks after surgical excision of the fistula. At this time the values approximated those obtained before operation with the fistula occluded (Figure 2).

Occlusion and release of a peripheral fistula in four patients produced no change in the diameter of the retinal vessels, observed with an ophthalmoscope.

\section{DISCUSSION}

Lewis and Drury (6) postulated that the cardiac output was not elevated in patients with arteriovenous fistulas since they could demonstrate no elevation of peripheral venous pressure. However, it has been shown repeatedly in animals ( 7 , 8) and man (9-11) that a large fistula is regularly accompanied by an increase in cardiac output. This was the case in the first four subjects of Table I. That cardiac output may not always be 
elevated in patients with small shunts is suggested by the findings in O. C. and H. F., as well as by the reports of others (12-14). Circulatory adjustment in such cases might be accomplished entirely by alterations in blood flow through other parts of the body. It is known, for example, that the flow of blood through uninvolved limbs $(8,9)$ and through the coronary bed $(15,16)$ may be reduced when an a-v fistula is opened and increased when the fistula is compressed.

When an a-v shunt is suddenly occluded and peripheral resistance abruptly increased, the arterial tree empties more slowly. Three factors may then contribute in varying degrees to a reduction in cardiac output: 1) reflex vagal slowing of the cardiac rate, mediated through aortic and carotid pressoreceptors, 2) an increase in the pressure in the aorta against which the left ventricle must discharge its load, and 3 ) a reduction in the inflow of blood to the right heart, resulting in decreased distention of the ventricles during diastole. A decrease in mean right atrial pressure has been reported (9) to coincide with the fall in cardiac output and stroke volume which followed occlusion of an arteriovenous fistula. Others, (17), however, have noted that the mean right arterial pressure may be unchanged when a fistula is occluded or released in the presence of large changes in cardiac output. In the present study examples of both relationships were seen. In considering the determinants of cardiac behavior under these conditions, it should be recalled that mean pressure in
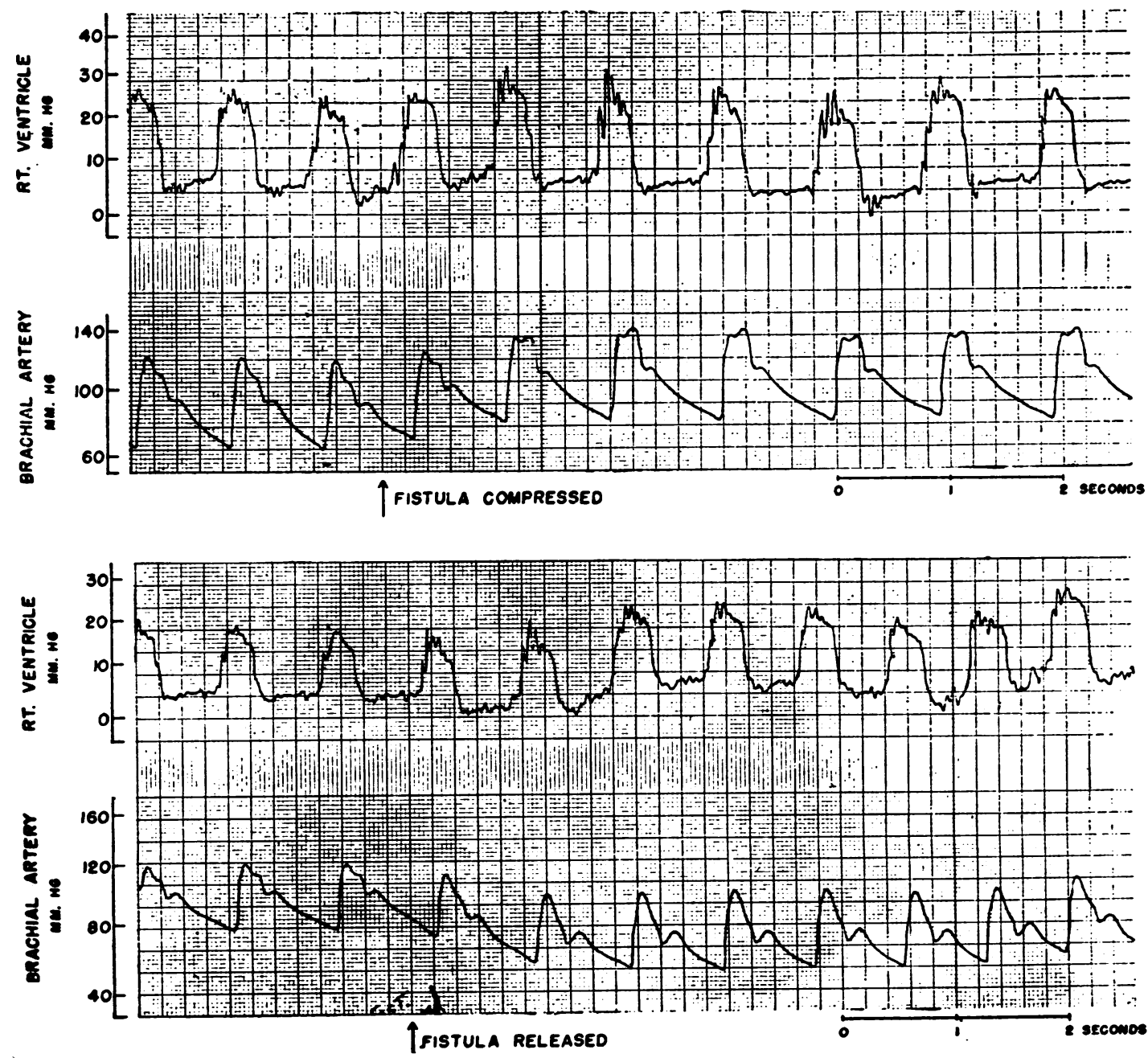

Fig. 1. Effect of Occluding and Releasing an a-v Fistula on Pressures in the Brachial Artery and Right Ventricle 
the right atrium may not mirror end diastolic pressure in the right ventricle (18) and that measured changes in pressure in atrium or ventricle may not accurately reflect changes in the length of the muscle fibres surrounding these chambers. Because of the distensibility characteristics of the great veins and right atrium at the ranges of pressure studied, an appreciable difference in the volume of blood contained in this system might not be detected from measurements of mean pressure alone. Without measurements of end diastolic volume, therefore, the applicability of Starling's law (19) to the behavior of the heart under these circumstances cannot be adequately assessed.

The decrease in mean pulmonary arterial pressure which occurred when an a-v shunt was occluded in patients F. R., H. B., A. D., and W. R. is consistent with the reports of Gibbon and Churchill (20) and Van Loo and Heringman (8) who recorded similar changes in anesthetized animals. Others have noted under the fluoroscope a decrease in distention of the pulmonary vasculature when a peripheral a-v fistula was compressed and an increase in width and density of these vessels when it was released (21). That these changes may not be detectable in all patients with an arteriovenous shunt (depending, perhaps, on the size of the fistula) is suggested by the absence of a change in pulmonary arterial pressure when the fistula was compressed in patients O. C. and

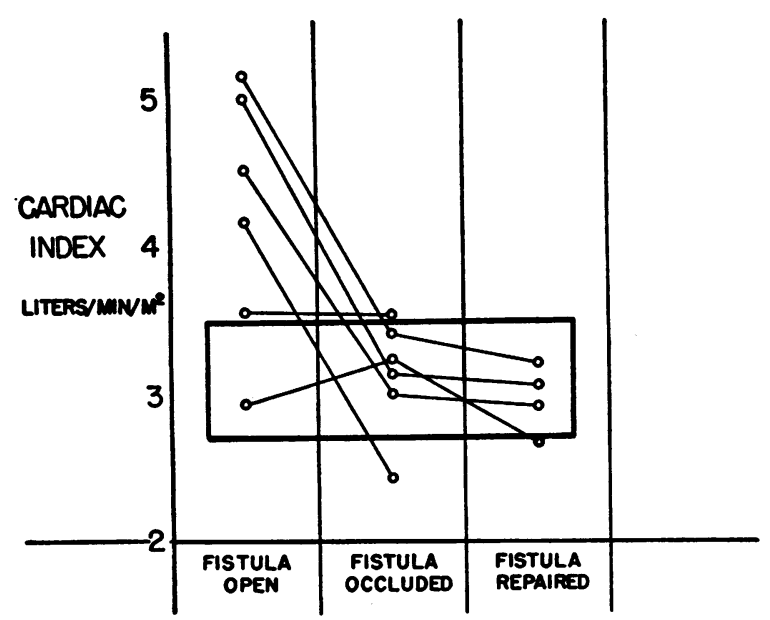

Fig. 2. Epfect on Cardiac Index of Occluding and Repairing an a-v Fistula

The black rectangle outlines the reported range of variation in cardiac index among normal subjects under resting conditions (5).
H. F., as well as in four cases reported by Warren, Brannon and Cooper (17). It would appear likely, from our own observations and those of others, that occlusion of a large arteriovenous fistula is followed by a redistribution of blood inside the vascular system, with a reduction in the volume of blood in the pulmonary arteries and perhaps the great veins and right heart, and an increase in the amount of blood distending the systemic arterial tree.

\section{SUM MARY}

Temporary occlusion of a peripheral arteriovenous fistula was followed by a fall in cardiac output and stroke volume in four out of six patients. Mean right atrial pressure, diastolic pressure in the right ventricle and mean pulmonary arterial pressure decreased slightly in some patients and did not change in others when the fistula was occluded.

\section{ACKNOWLEDGMENT}

The authors wish to express their gratitude to Dr. Donald E. Gregg for assistance in the actual experiments reported, for constructive suggestions in the preparation of this paper and for his invaluable advice, encouragement, and friendship.

\section{REFERENCES}

1. Friedlich, A., Heimbecker, R., and Bing, R. J., Device for continuous recording of concentration of Evans blue dye in whole blood and its application to determination of cardiac output. J. Applied Physiol., 1950, 3, 12.

2. Shadle, O. W., Ferguson, T. B., Gregg, D. E., and Gilford, S. R., Evaluation of a new cuvette densito meter for determination of cardiac output. Circulation Research, Vol. I., in press.

3. Nicoladoni, C., Phlebarteriectasie der rechten oberen Extremität. Arch. f. klin. Chir., 1875, 18, 252.

4. Branham, H. H., Aneurysmal varix of the femoral artery and vein following a gunshot wound. Internat. J. Surg., 1890, 3, 250.

5. Ferrer, M. I., Harvey, R. M., Cathcart, R. T., Webster, C. A., Richards, D. W., Jr., and Cournand, A., Some effects of digoxin upon the heart and circulation in man. Digoxin in chronic cor pulmonale. Circulation, 1950, 1, 161.

6. Lewis, T., and Drury, A. N., Observations relating to arterio-venous aneurism. Heart, 1923, 10, 301.

7. Harrison, T. R., Dock, W., and Holman, E., Experimental studies in arterio-venous fistulae: cardiac output. Heart, 1924, 11, 337. 
8. Van Loo, A., and Heringman, E. C., Circulatory changes in the dog produced by acute arteriovenous fistula. Am. J. Physiol., 1949, 158, 103.

9. Cohen, S. M., Edholm, O. G., Howarth, S., McMichael, J., and Sharpey-Schafer, E. P., Cardiac output and peripheral blood flow in arteriovenous aneurysm. Clin. Sc., 1948, 7, 35.

10. Smith, C., Circulation in arteriovenous aneurysm before and after operation. Arch. Int. Med., 1931, 48, 187.

11. Kennedy, J. A., and Burwell, C. S., Measurements of the circulation in a patient with multiple arteriovenous connections. Am. Heart J., 1944, 28, 133.

12. Warren, J. V., Nickerson, J. L., and Elkin, D. C., The cardiac output in patients with arteriovenous fistulas. J. Clin. Invest., 1951, 30, 210.

13. Ellis, L. B., and Weiss, S., The local and systemic effects of arterio-venous fistula on the circulation in man. Am. Heart J., 1930, 5, 635.

14. Taquini, A. C., and Suarez, J. R. E., Modificaciones respiratorias $\mathrm{y}$ circulatorias en los aneurismas arteriovenosos. Medicina, 1945, 5, 109.
15. Smith, F. M., Miller, G. H., and Graber, V. C., The relative importance of the systolic and the diastolic blood pressure in maintaining the coronary circulation. Arch. Int. Med., 1926, 38, 109.

16. Green, H. D., The coronary blood flow in aortic stenosis, in aortic insufficiency and in arteriovenous fistula. Am. J. Physiol., 1936, 115, 94.

17. Warren, J. V., Brannon, E. S., and Cooper, F. W., Jr., The hemodynamics of rapid changes in cardiac output in man. J. Clin. Invest., 1947, 26, 1199.

18. Gregg, D. E., Coronary Circulation in Health and Disease. Lea \& Febiger, Philadelphia, 1950.

19. Starling, E. H., The Law of the Heart (Linacre Lecture, given at Cambridge, 1915). Longmans, Green and Co., London, 1918.

20. Gibbon, J. H., Jr., and Churchill, E. D., Changes in the pulmonary circulation induced by experimentally produced arteriovenous fistula. Arch. Surg., 1930, 21, 1188.

21. Laplace, L. B., Observations on the effect of an arteriovenous fistula on the human circulation. Am. J. M. Sc., 1935, 189, 497. 